GRASAS Y ACEITES 72 (3)

July-September 2021, e422

ISSN-L: 0017-3495

https://doi.org/10.3989/gya.0664201

\title{
Phenomenological model for the prediction of Moringa oleifera extracted oil using a laboratory Soxhlet apparatus
}

\author{
๑Y. Díaz ${ }^{\mathrm{a}, 凶}, \oplus \mathrm{D}$. Tabio ${ }^{\mathrm{a}}, \oplus \mathrm{M}$. Rondón ${ }^{\mathrm{a}}, \oplus \mathrm{R}$. Piloto-Rodríguez ${ }^{\mathrm{b}}$ and $\oplus \mathrm{E}$. Fernández ${ }^{\mathrm{a}}$ \\ aFaculty of Chemical Engineering, Universidad Tecnológica de La Habana José A. Echeverría, Cujae, 19390, La Habana, Cuba. \\ ${ }^{\mathrm{b}}$ Center of Studies for Renewable Energies, Universidad Tecnológica de La Habana José A. Echeverría, Cujae, 19390, La Habana, Cuba. \\ ${ }^{\square}$ Corresponding author: ydiaz@quimica.cujae.edu.cu
}

Submitted: 14 June 2020; Accepted: 15 July 2020; Published online: 20 September 2021

\begin{abstract}
SUMMARY: Moringa oleifera is an oilseed crop with potential for biodiesel production. The second step in this process is the extraction of oil. Extraction in hot water, with a Soxhlet apparatus and the ultrasound technique are the most commonly used methods. The aim of the present work was to obtain a phenomenological model for the Moringa oleifera oil extraction process using Soxhlet. Effective diffusivity for Moringa oil through the kernels is obtained, using the kinetics of the extraction process (experimentally determined) and the Fick's diffusion second law for non-steady state. The value of $0.685 \cdot 10^{-12} \mathrm{~m}^{2} / \mathrm{s}$ fully matched reports on effective diffusion coefficient for other solids. It was also verified from the statistical analysis and a linear fit for experimental data that the model can be used to describe the oil extraction process of Moringa oleifera in the Soxhlet extractor, responding to the diffusive phenomenon (process controlled by internal resistance).
\end{abstract}

KEYWORDS: ANOVA; Effective diffusivity; Kinetics; Moringa oleifera seed oil; Phenomenological model; Soxhlet extraction

RESUMEN: Modelo fenomenológico para la predicción del aceite extraído de Moringa oléfera utilizando un equipo de laboratorio Soxhlet. Moringa oleifera es un cultivo oleaginoso con potencial para producir biodiesel. La segunda etapa del proceso es la extracción de aceite. Los métodos más utilizados son la extracción en agua caliente, con Soxhlet y la técnica de ultrasonidos. El objetivo del trabajo fue obtener un modelo fenomenológico para el proceso de extracción de aceite de Moringa oleífera en Soxhlet. Utilizando la cinética del proceso extractivo (determinada experimentalmente) y la segunda ley de difusión de Fick en estado no estacionario, se obtuvo la difusividad efectiva del aceite de Moringa a través de los cotiledones. El valor de $0.685 \cdot 10^{-12} \mathrm{~m}^{2} / \mathrm{s}$, se corresponde con reportes del coeficiente de difusión efectiva para otros sólidos. Se verificó a partir del análisis estadístico y ajuste lineal de los datos experimentales, que el modelo describe el proceso de extracción de aceite de Moringa oleífera en Soxhlet, respondiendo al fenómeno difusivo (proceso controlado por la resistencia interna).

PALABRAS CLAVE: Aceite de semillas de Moringa oleifera; Análisis de varianza; Cinética; Difusividad efectiva; Extracción con Soxhlet; Modelo fenomenológico

Citation/Cómo citar este artículo: Díaz Y, Tabio D, Rondón M, Piloto-Rodríguez R, Fernández E. 2021. Phenomenological model for the prediction of Moringa oleifera extracted oil using a laboratory Soxhlet apparatus. Grasas Aceites 72 (3), e422. https://doi. org/10.3989/gya.0664201

Copyright: (C2021 CSIC. This is an open-access article distributed under the terms of the Creative Commons Attribution 4.0 International (CC BY 4.0) License. 


\section{INTRODUCTION}

According to several reports, Moringa oleifera Lam. is an oilseed crop with potential for biodiesel production (Rahid et al., 2008; Rashid et al., 2011). The Moringaceae plant family consists of 12-14 species belonging to only one genus, Moringa (Díaz et al., 2019). Moringa oleifera is native to Asia, Africa and Arabia. The height of the tree can reach 10 $\mathrm{m}$. It can grow well in the humid tropical or hot dry lands; it can survive in very poor soils and is hardly affected by drought (Anwar and Bhanger, 2003; Díaz et al., 2017). Seeds are fleshy, and covered by a fine husk of coffee color. They have three wings, or winged seeds from 2.5 to $3 \mathrm{~mm}$ in length. The kernel-to-husk percentage ratio of the whole seed is approximately 75:25 (Salaheldeen et al., 2014).

The seed kernels contain a significant amount of oil, commercially known as "Ben oil" or "Behen oil" (Anwar and Bhanger, 2003). The oil content and its properties widely vary depending mainly on the species and environmental conditions (Adegbe et al., 2016). The oil produced from the seed kernel of Moringa oleifera is golden yellow and contains high amounts of oleic acid, with approximately $75 \%$. The ester profile of Moringa oleifera oil differs from other common vegetable oils used as biodiesel feedstocks, and influences fuel properties. It may also be noted that oils with high oleic acid contents could have a positive influence on fuel properties (Díaz et al., 2019).

Moringa oleifera seeds have also been used as an effective coagulant and antimicrobial agent to remove hardness, undesirable chemicals and biological contaminants from water (Falowo et al., 2018; Kayode and Kabir, 2018). The active agents of coagulation are dimeric cationic proteins of molecular weight of approximately 13 kilodaltons (kDa) (Prasad, 2009).

The second step in biodiesel production from oilseeds is the extraction of oil. The husk and remaining cake are generated as by-products. Extraction of vegetable oil is commonly based on mechanical pressing and solvent extraction (Reverchon et al., 1999). It is well-known that oil extraction efficiency by mechanical pressing is significantly lower than chemical extraction. Nevertheless, by solvent extraction, chemical residues could remain, which can be quite harmful to human health and to the environment (Zhao and Zhang, 2013). Due to this fact, after solvent extraction, a step of solvent-removal by vacuum evaporation is applied (Stamenković et al., 2018). Extraction in hot water with Soxhlet apparatus and the ultrasound technique are the most commonly used methods.

The solvent extraction of vegetable oil is usually carried out with hexane (Kostic et al., 2014). For the extraction process, vegetable oils can be referred to as a simple component, since all glycerides are soluble in hexane. The other components that are extracted with some difficulty are phosphatides, since they have limited solubility.

Solvent extraction modeling. During solvent extraction, oil seeds are put in contact with the pure solvent or a solvent mix to transfer the oil from the solid matrix to the fluid medium. This is developed following a complex mechanism, especially for oil materials because of the cell structure of vegetable lipidic thickness. For that reason, it is difficult to explain all phenomena which take place during the solvent extraction through a single theory (Carrin and Craspite, 2008). Different authors have considered the mathematic modeling of vegetable oil extraction (Thomas et al., 2005).

Diffusive transport. The success of an industrial extraction process is a function of how fast a compound dissolves. Different phenomena are involved in the passage of the solute from the solid to the solvent. The oil diffuses through the internal structure to the surface of the solid and then passes into the liquid by a convective mechanism (external transport) (Treybal, 2001). Therefore, the convective transport of oil into the liquid phase and the diffusive transport produced within the solid must be evaluated in order to characterize the transfer of matter.

The traditional Fickian approach uses the concentration gradient between the raw material particles and the solution as the driving force of the extraction (Doulia and Gekas, 2001). This development can be used (considering that there are no changes in the effective diffusivities with the solute concentration and that external resistance to mass transfer is negligible) using a distribution coefficient between two phases and with diluted extracts. Thus, the extraction rate increases with increasing concentration gradient. It can also be increased by increasing the diffusion coefficient or by reducing the particle size (Cacace and Mazza, 2003). The diffusion coefficient is frequently 
reported as the effective diffusion coefficient.

From the above, it is important to know the phenomenological characterization of the oil extraction process. Numerical modeling and simulation are important substitutes of the experiments. The advantages of modeling and simulation are cost and time saving. The best type of model is phenomenological. It is based on physical and/or chemical principles. Nevertheless, a model requires empirical validation (Muharam et al., 2019). Numerical modeling and simulation research on Moringa oleifera oil production through solvent extraction are not reported.

The aim of the present work was to obtain a phenomenological model for the Moringa oleifera oil extraction process using Soxhlet apparatus.

\section{MATERIALS AND METHODS}

\subsection{Seed origin}

The seeds of Moringa oleifera were harvested at a facility located at $\left(23^{\circ} 7^{\prime} 0^{\prime \prime} \mathrm{N}, 82^{\circ} 23^{\prime} 0^{\prime \prime} \mathrm{W}\right)$ in Havana, Cuba. They were globular, three-winged seeds and covered with a thick blackish seed coat. The weight of 100 seeds of Moringa oleifera was found to be 23.90 $\mathrm{g} \pm 0.38$. The seed contained $72.74 \% \pm 1.26$ kernels and $27.26 \% \pm 1.21$ husks. According to literature reports (Salaheldeen et al., 2014; Díaz et al., 2017), the contents and properties of Moringa seeds depend on species and environmental conditions. After removing the husk, the kernels were milled and dried.

\subsection{Particle size}

The size-reduced particles were analyzed using the Cuban standard (NC, 2008). A representative sample of $14 \mathrm{~g}$ of milled kernels was taken, according to the standard report. The average diameter of the particle conglomerate $(\mathrm{Dp})$ in $\mathrm{m}$ was determined from Equation 1 (Rosabal and Garcel, 2006).

$$
\mathrm{Dp}=\frac{1}{\sum \frac{\Delta \mathrm{xi}}{\mathrm{Dpi}}}
$$

Where $\Delta \mathrm{xi}$ is the retained fraction in the bottom sieve of each pair and Dpi the average size of the particles retained in the bottom sieve of each pair.

\subsection{Drying of milled kernels}

The milled kernels were dried at $55{ }^{\circ} \mathrm{C}$ in a stove (model DHG 9146A, Shanghai Huitai Instrument Manufacturing CO., LTD, Shanghai, China). Removing water during this operation made the oil extraction more efficient, since drying favored the breakdown of the water-oil emulsions, guaranteeing the oil easily dissolved in the organic solvent. The moisture determination was carried out by weighing the difference using an analytical balance, model SARTORIUS BS 124S. The drying curve was obtained to define the operation time. Weighing was carried out every half hour until reaching constant weight.

\subsection{Oil extraction}

A lab scale Soxhlet apparatus fitted with a 1-L round-bottom flask and a condenser was used to extract the oil from the kernels. About $10 \mathrm{~g}$ of dried sample were used for each extraction. Hexane (purity $>98 \%$, specific gravity: 0.659 , refractive index: $1.375)$ was added as solvent according to a solventkernels ratio (6:1) (mass: volume ratio) in accordance with previous studies (Díaz et al., 2017; Tabio et al., 2018). An evaporation process was applied to the mixture of oil and solvent in order to remove one from the other. The process was developed in a rotary evaporator (IKA-WERK HB 4 basic, Germany). The extracted oil yield was expressed in mass percentage, which is defined as the weight of the oil extracted over the weight of the sample.

\subsection{Kinetics of the process}

The extraction kinetics of the Moringa oil were studied in the Soxhlet using hexane at $69^{\circ} \mathrm{C}$ (boiling temperature) as solvent. During the experimental runs, the change in time of the extracted oil percentage was obtained. The measurements were carried out in triplicate.

\subsection{Diffusion model and effective diffusivity coefficient determination}

The calculation method to apply the solution to Fick's diffusion second law, using natural logarithms was followed by a simple regression analysis of the solute's adimensional concentration with respect to time.

Oilseeds have a cellular structure. Therefore, the internal diffusion within the solid structure is the determining mechanism of the extraction rate. Therefore, this type of phenomenon is represented 
by Fick's diffusion second law for a non-steady state (Varzakas et al., 2005). To obtain the effective diffusivity coefficient, the kinetics of the extractive process must be experimentally determined and the aforementioned law must be used. Fick's diffusion second law for non-steady state was used to assess whether the extraction of Moringa oleifera oil using Soxhlet was controlled by internal resistance (diffusive transport). To mathematically model the diffusion according to this law, the following conditions must be taken into account:

- The diffusion coefficient must be an independent constant of the solid particle radius

- The solid structure must be homogeneous and isotropic

- The oil distribution in the cell must be uniform

- In the case of spheres, the solid particle radius must be uniform and the same for all particles

- Mass transfer from solid to liquid phase is considered to be dominated by internal resistance (diffusive transport)

The effective diffusivity of the solid is constant throughout the sphere and the differential equation that describes the diffusion process in spherical coordinates can be obtained according to Hinnes et al. (1987) (Equation 2).

$$
\frac{\partial \mathrm{c}}{\partial \mathrm{t}}=\mathrm{D}_{\mathrm{ef}} \cdot\left(\frac{\partial^{2} \mathrm{c}}{\partial \mathrm{r}^{2}}+\frac{2 \partial \mathrm{c}}{\mathrm{r} \partial \mathrm{r}}\right)
$$

Where $\frac{\partial \mathrm{c}}{\partial \mathrm{t}}$ is the cumulative term, $\frac{\partial^{2} \mathrm{c}}{\partial \mathrm{r}^{2}}+\frac{2 \partial \mathrm{c}}{\mathrm{r} \partial \mathrm{r}}$ the diffusive term, $r$ the sphere radius in $\mathrm{m}, \mathrm{t}$ is the time of diffusion in $\mathrm{s}$ and Def are the effective diffusivity coefficients of solute in $\mathrm{m}^{2} / \mathrm{s}$.

To model the mass transfer, an initial and boundary conditions are required:

For $\mathrm{t}=0 \mathrm{c}=\mathrm{c}_{0}\left(\mathrm{c}_{0}\right.$ : initial solute concentration $\left.(\mathrm{g} / \mathrm{mL})\right)$

For $\mathrm{t}>0 \mathrm{c}=0$ at $\mathrm{r}=\mathrm{a}$, a: Radius on the surface of the sphere

The differential equation mathematics solution can be determined from Equation 3:

$$
\frac{\mathrm{c}}{\mathrm{c}_{0}}=\frac{2 \mathrm{a}}{\pi} \sum_{\mathrm{n}=1}^{\infty} \frac{(-1)^{\mathrm{n}}}{\mathrm{n}} \cdot \mathrm{e}^{\frac{\mathrm{Des}_{\mathrm{c}} \mathrm{n}^{2} \pi^{2} \mathrm{t}}{\mathrm{a}^{2}}} \cdot \operatorname{sen} \frac{\mathrm{n} \pi \mathrm{r}}{\mathrm{a}}
$$

Because triglycerides have different molecular structures and masses, it is better to measure the amount of oil with respect to the solid mass. Therefore, the concentration ratio $\frac{\mathrm{c}}{\mathrm{c}_{0}}$ is transformed into the relationship between the remaining oil mass (q) and the initial mass of oil $\left(\mathrm{q}_{0}\right)$, obtaining the $\frac{\mathrm{q}}{\mathrm{q}_{0}}$ ratio.

For longer times, series converge and, consequently, for most practical calculations, a few points are sufficient. Indeed, all the series points, except the first one, are negligible. The solution of Fick's diffusion second law is reduced to Equation 4, where the amount of solute remaining in the solid at time $t$ with respect to the initial amount is:

$$
\frac{\mathrm{q}}{\mathrm{q}_{0}}=\frac{6}{\pi^{2}} \cdot \mathrm{e}^{-\pi^{2}} \cdot \frac{\mathrm{D}_{\mathrm{ec}}}{\mathrm{r}^{2}} \cdot \mathrm{t}
$$

Where $\frac{\mathrm{q}}{\mathrm{q}_{0}}$ is the relationship between the remaining and initial quantity of oil, q the amount of remaining oil in $g$ at time $t, q_{0}$ the initial amount of oil in $g$ and $\pi$ is the mathematical constant 3.1418.

Equation 4 was linearized by applying natural logarithms to obtain Equation 5. The fit models were tested for fit quality. For simple regression analysis, the Statgraphics Centurion statistical program, version XV was used. The slope of the line was used to estimate the effective diffusion coefficient. An initial oil content $\left(\mathrm{c}_{0}\right)$ of $45 \%$ was considered since it is the maximum reported by Abdulkareem et al. (2011); Ayerza (2011) and Efeovbokhan et al. (2015) for Moringa oleifera. The equivalent radius of the sphere was taken as the average radius of the particle conglomerate obtained by the sieving operation.

$$
\ln \frac{\mathrm{q}}{\mathrm{q}_{0}}=-0.498-\frac{9.87 \mathrm{D}_{\mathrm{ef}}}{\mathrm{r}^{2}} \cdot \mathrm{t}
$$

\section{RESULTS AND DISCUSSION}

\subsection{Sieving analysis}

The sieving analysis served to obtain the distribution of the present size of particles in the Moringa oleifera seeds kernels after the milling process (Table 1 and Figure 1).

A varied distribution of particle sizes can be observed in Figure 1. The largest amount of milled seeds kernels $(56.09 \%)$ began to cluster in smaller diameter sieves (between $1.0 \cdot 10^{-3}$ and $0.5 \cdot 10^{-3} \mathrm{~m}$ ). 
TABLE 1. Sieving analysis data of Moringa oleifera milled kernels

\begin{tabular}{cccc}
\hline $\begin{array}{c}\text { Sieves breach } \\
\text { relationship }\end{array}$ & Retained mass $(\mathbf{g})$ & $\mathbf{\Delta x i}$ & $\mathbf{D p i} \cdot \mathbf{1 0}^{\mathbf{3}}$ \\
\hline 2.000 & 1.57 & 0.107 & 2.000 \\
$2.000 / 1.600$ & 0.74 & 0.051 & 1.800 \\
$1.600 / 1.400$ & 0.80 & 0.055 & 1.500 \\
$1.400 / 1.000$ & 2.35 & 0.161 & 1.200 \\
$1.000 / 0.800$ & 1.22 & 0.084 & 0.900 \\
$0.800 / 0.630$ & 2.16 & 0.148 & 0.715 \\
$0.630 / 0.500$ & 2.46 & 0.168 & 0.565 \\
$0.500 / 0.400$ & 0.35 & 0.024 & 0.450 \\
$0.400 / 0.315$ & 0.93 & 0.064 & 0.357 \\
$0.315 / 0.200$ & 1.69 & 0.116 & 0.257 \\
$0.200 / 0.160$ & 0.27 & 0.018 & 0.180 \\
$0.160 / 0.125$ & 0.06 & 0.004 & 0.142 \\
0.125 & 0.00 & - & 0.125 \\
\hline
\end{tabular}

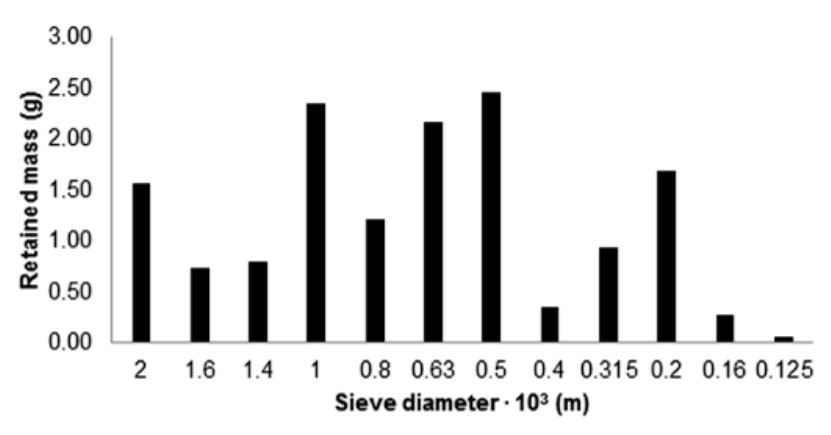

FIGURE 1. Particle size distribution of Moringa oleifera milled kernels.

The average diameter of the particle conglomerate (determined by Equation 1) was $0.602 \cdot 10^{-3} \mathrm{~m}$. This result corroborates the fact that with this milling method it was possible to further decrease the particle size and therefore the oil extraction process was expected to be favored.

It has been reported (Abdulkareem et al., 2011) that particle size can directly affect the rate and yield of the extraction process. Generally, at smaller particle sizes the contact area between the solvent and the solid increases, which caused the oil transfer rate to increase (Abdulkareem et al., 2011).

Abdulkareen et al. (2011), recommend a small size range (between $0.7 \cdot 10^{-3}$ and $0.5 \cdot 10^{-3} \mathrm{~m}$ ) so that each particle required approximately the same extraction time. The results obtained in the present work are in agreement with this aspect, the average diameter of the milled seeds kernels being included in the aforementioned interval. The diffusion coefficient for internal mass transport depends of the solid structure. To reduce the particle size of oilseeds the cellular wall is broken, thus increasing the access to the lipid content. It means that oil could be extracted with a higher extraction rate.

\subsection{Moisture content of the seed kernels}

The initial moisture content of Moringa oleifera seeds kernels was $4.61 \%$. This result was found to be lower than that of Moringa oleifera from Pakistan (5.70\%) and Yucatan (5.84\%) (Anwar and Bhanger, 2003; Ortiz et al., 2012). However, the above-mentioned moisture reports are related to the whole seed (husk and kernel). For this reason, the husk moisture content of Moringa oleifera from Cuba should be taken into account to make a precise comparison. Recently a husk moisture content of $6.25 \%$ was reported for Moringa oleifera grown in Cuba (Pfeil et al., 2020). Therefore, a seed moisture content of $5.05 \%$ could be obtained by mass balance using this last value.

The drying curve serves to determine the moisture content of the kernels at any instant in time. The results are shown in Figure 2.

The moisture content of Moringa oleifera seed kernels decreased from 4.61 to $0.22 \%$ during the drying process as can be seen in Figure 2. From the aforementioned, a drying time of two hours was established because the moisture decreased to percentages lower than $0.3 \%$.

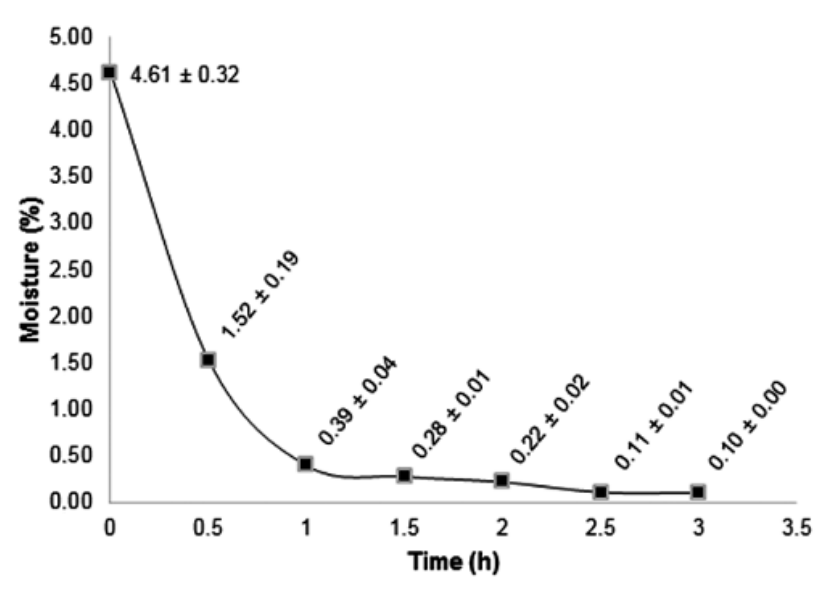

FIGURE 2. Drying curve of Moringa oleifera kernels at $55^{\circ} \mathrm{C}$. Each moisture percentage is an average of three determinations, mean $\pm \mathrm{SD}$. 


\subsection{Kinetics of extractive process}

The results for kinetic extraction are shown in Figure 3.

An oil extraction behavior over time is observed in Figure 3, which indicated, as expected, that oil yield is time dependent. The amount of extracted oil is practically constant for extraction times of six hours and longer, which was demonstrated with the asymptotic behavior of the curve. The high rate of extraction observed at the early stages may be due to the high solubility of the oil in the freshly charged solvent and the high concentration of the oil at the solid surface. The freshly charged solvents (lean oil) created a positive gradient or the needed driving force that resulted in a higher mass transfer rate of oil in to the extracting solvents. After the optimum point had been reached, the extracting solvents (oil rich) gave rise to lower driving force or slower extraction rates (Efeovbokhan et al., 2015). The experimental kinetics of the extractive process were required to determine the effective diffusivity coefficient.

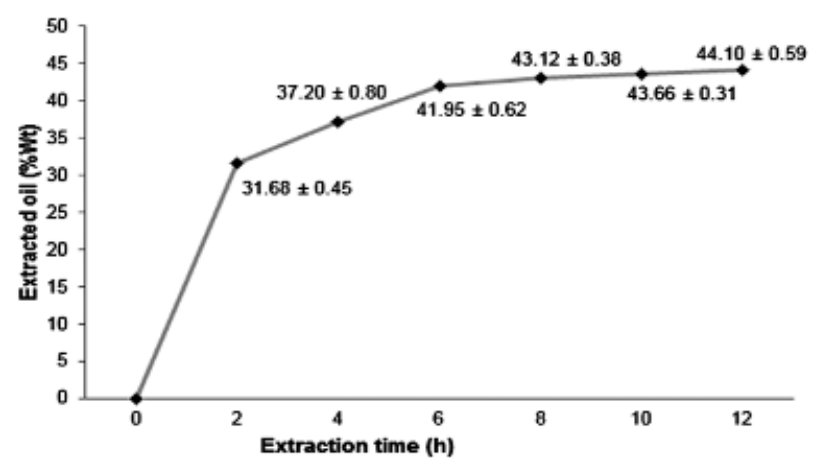

FIGURE 3. Extraction kinetic curve of Moringa oleifera seed oil using hexane. The extracted oil percentages are expressed as means \pm SD of triplicate experiments.

\subsection{Phenomenological model of extraction}

It should be expected that internal mass transport will be the controlling phase during the extraction process of Moringa oleifera oil using Soxhlet apparatus because of the cellular structure of abovementioned oilseed. This phenomenon was verified through Fick's diffusion second law in a non-steady state, taking into account the kinetics of the extraction process as shown in Figure 3. Fick's mathematic solution was linearized by applying the natural logarithms in Equation 5.
The established initial oil content of Moringa oleifera kernels and sample mass were $45 \%$ and $10 \mathrm{~g}$, respectively. The remaining oil content was calculated as a mass fraction per unit of initial oil mass $\left(\frac{\mathrm{q}}{\mathrm{q}_{0}}\right)$. Table 2 shows the experimental remaining oil masses determined from kinetics extraction with hexane.

A linear fit was corroborated for the experimental data when $\ln \left(\mathrm{q} / \mathrm{q}_{0}\right)$ is plotted against time (Figure 4).

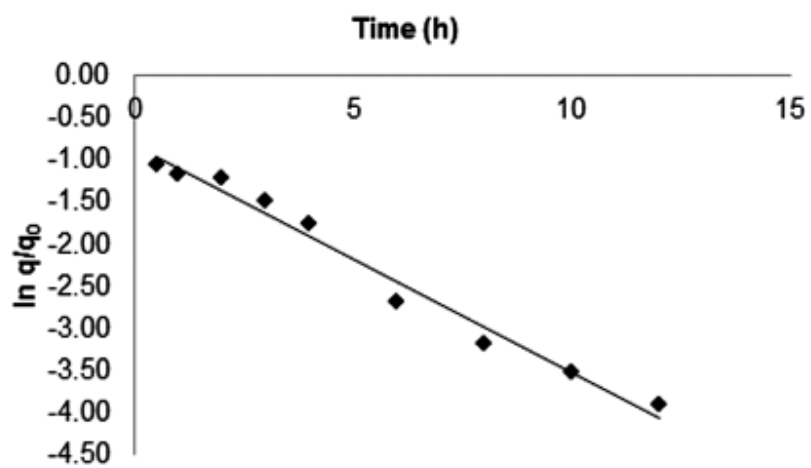

FiguRE 4. Experimental data fitting to the Fick's diffusion second law for non-steady state

The model obtained is represented by Equation (6):

$$
\ln \frac{\mathrm{q}}{\mathrm{q}_{0}}=-0.2689 \cdot \mathrm{t}-0.8302
$$

TABLE 2. Experimental values for Moringa oleifera remaining oil from kinetic study with hexane at $69^{\circ} \mathrm{C}\left(\mathrm{q}_{0}=4.5 \mathrm{~g}\right)$

\begin{tabular}{ccccc}
\hline $\begin{array}{c}\text { Time } \\
\text { (h) }\end{array}$ & $\begin{array}{c}\text { Extracted oil } \\
\text { fraction from } \\
\text { the kernels } \\
\text { (Mean } \pm \text { SD)* }\end{array}$ & $\begin{array}{c}\text { Remaining } \\
\text { oil }[\mathbf{q}] \mathbf{( g )}\end{array}$ & $\begin{array}{c}\text { Remaining } \\
\text { oil/initial oil } \\
\text { ratio }\left[\mathbf{q} / \mathbf{q}_{\mathbf{0}}\right]\end{array}$ & $\mathbf{\text { In(q/q } \mathbf { 0 } )}$ \\
\hline 0.5 & $0.2942 \pm 0.0074$ & 1.558 & 0.346 & -1.0607 \\
1.0 & $0.3096 \pm 0.0092$ & 1.404 & 0.312 & -1.1648 \\
2.0 & $0.3168 \pm 0.0045$ & 1.332 & 0.296 & -1.2174 \\
3.0 & $0.3483 \pm 0.0051$ & 1.017 & 0.226 & -1.4872 \\
4.0 & $0.3720 \pm 0.0080$ & 0.780 & 0.173 & -1.7527 \\
6.0 & $0.4195 \pm 0.0062$ & 0.305 & 0.068 & -2.6927 \\
8.0 & $0.4312 \pm 0.0038$ & 0.188 & 0.042 & -3.1756 \\
10.0 & $0.4366 \pm 0.0031$ & 0.134 & 0.030 & -3.5166 \\
12.0 & $0.4410 \pm 0.0059$ & 0.090 & 0.020 & -3.9120 \\
\hline
\end{tabular}

*Values are expressed as means \pm standard deviation (SD) of triplicate experiments. 
Phenomenological model for the prediction of Moringa oleifera extracted oil using a laboratory Soxhlet apparatus $\bullet$

TABLE 3. ANOVA of the phenomenological model for Moringa oleifera oil extraction process using Soxhlet

\begin{tabular}{|c|c|c|c|c|c|}
\hline Source & Sum of Squares & DF & Mean Square & F-Ratio & P-Value \\
\hline Model & 9.69578 & 1 & 9.69578 & 334.56 & 0.0000 \\
\hline Residual & 0.202865 & 7 & 0.0289808 & & \\
\hline Total (corr.) & 9.89865 & 8 & & & \\
\hline Correlation coefficient & -0.9897 & & & & \\
\hline $\mathrm{R}^{2}$ & $97.95 \%$ & & & & \\
\hline $\mathrm{R}^{2}$ (adjusted for $\mathrm{DF}$ ) & $97.66 \%$ & & & & \\
\hline Standard Error of Est. & 0.170237 & & & & \\
\hline Mean absolute Error & 0.134161 & & & & \\
\hline Durbin-Watson statistic & $\begin{array}{c}1.33855 \\
(\mathrm{P}=0.0560)\end{array}$ & & & & \\
\hline Lag1 residual autocorrelation & 0.255402 & & & & \\
\hline
\end{tabular}

TABLE 4. Statistical significance of the phenomenological model coefficients

\begin{tabular}{lcccc}
\hline Parameter & $\begin{array}{c}\text { Least } \\
\text { Squares }\end{array}$ & $\begin{array}{c}\text { Standard } \\
\text { Error }\end{array}$ & t statistic & P-Value \\
\hline Intercept & -0.830176 & 0.09483 & -8.7540 & 0.0001 \\
Slope & -0.268992 & 0.01470 & -18.2910 & 0.0000 \\
\hline
\end{tabular}

The tests of model fit were verified to validate the quality. The analysis of variance (ANOVA) of the model and the statistical significance of its parameters are presented in Tables 3 and 4.

Since the P-value in the ANOVA table is less than 0.05 , there is a statistically significant relationship between $\ln \left(\mathrm{q} / \mathrm{q}_{0}\right)$ and time at the $95.0 \%$ confidence level. The R-Squared statistic indicates that the model as fitted explains $97.9506 \%$ of the variability in $\ln \left(\mathrm{q} / \mathrm{q}_{0}\right)$. The correlation coefficient equals -0.9897 , indicating a relatively strong relationship between the variables.

The adjusted $\mathrm{R}^{2}$ statistic, which is more suitable for comparing models with different numbers of independent variables, was $97.65 \%$. The high value of the determination coefficient $\mathrm{R}^{2}$ justified a good correlation between the parameter and for this reason, the model is suitable for a satisfactory representation of the real process.

The Durbin-Watson (DW) statistic tests the residuals to determine if there is any significant correlation based on the order in which they occur in the data. Since the P-value (0.0560) is greater than
$5.0 \%$, there is no indication of serial autocorrelation in the residuals at the $5.0 \%$ significance level. The residuals, which are the difference between the observed values and the predicted values, should lie on a straight line in the normal probability plot.

Therefore, these three suppositions imply that the suggested model (Equation 6) is adequate and can be used to describe the oil extraction process of Moringa oleifera in the Soxhlet extractor, responding to the diffusive phenomenon according to Fick's diffusion second law in a non-steady state.

\subsection{Comparative analysis of oil extraction percentages determined from the phenomenological model and laboratory experiments}

Three oil extraction experiments were developed according to the description in the materials and methods section. For any extraction process, it is possible to obtain a high quantity of the product in the first hours, with a time from which the effectiveness of the extraction is very low. The difference between the overall maximum at $12 \mathrm{~h}$ and the value at 6 $h$, as obtained from the respective seed samples, extracting solvent and times was only nominal (see Figure 3). That is the main reason for fixing six hours as the extraction time for the experiments. This would not affect the oil extraction percentage and will be related to the energy consumption during the operation with the Soxhlet apparatus. This means that if the cost of solvent extraction is considered, the optimum conditions must be used. The nominal oil yield after this optimum point bears a negative 
cost on the overall extraction cost (Efeovbokhan et al., 2015).

The experimental extraction oil percentages of Moringa oleifera from Cuba were 40.12, 40.56 and $42.48 \%$. These results were higher than those reported for Moringa oleifera Wild (NWFP, Pakistan) $34.80 \%$ and Moringa oleifera variety Mbololo (Kenya) $35.70 \%$. However, the extracted oil content was comparable to Moringa oleifera Sindh (Pakistan) 40.39\% (Anwar and Rashid, 2007). The differences found might be attributed to the diversity of natural habitats and agroclimatic constraints (Efeovbokhan et al., 2015).

In addition, the extraction percentage obtained from the phenomenological model $(41.09 \%)$ was compared to the experimental results. The relative error was lower than $5 \%$ in all cases, which validated the degree of accuracy of the phenomenological model to predict the extraction percentage of Moringa oleifera oil in Soxhlet.

\subsection{Effective diffusivity estimation of Moringa oleifera oil through the kernels}

The effective diffusivity (Def) was obtained from the slope of the fitted model (Equation 6). The equivalent sphere radius was $0.301 \cdot 10^{-3} \mathrm{~m}$ as calculated from the average diameter of the particle conglomerate $\left(0.602 \cdot 10^{-3} \mathrm{~m}\right)$. The effective diffusivity for Moringa oleifera oil through the kernels was obtained for the first time. The value of $0.685 \cdot 10^{-12}$ $\mathrm{m}^{2} / \mathrm{s}$, fully matched with reports of effective diffusion coefficient (between $10^{-12}$ to $10^{-10} \mathrm{~m}^{2} / \mathrm{s}$ ) for other solids (Doulia and Gekas, 2001; Cacace and Mazza, 2003; Varzakas et al., 2005). Diffusion within a solid structure is a more complex phenomenon than inside liquids and gases. For this reason, lower diffusion coefficient and slower mass transfer are to be expected.

\section{CONCLUSIONS}

A phenomenological model to describe the oil extraction process using Soxhlet was obtained. The validity of the model was demonstrated when Fick's diffusion second law in a non-steady state was applied to the oil extraction from Moringa oleifera kernels with hexane. The extraction percentage determined from the phenomenological model $(41.09 \%)$ was compared to the experimental results. The relative error was lower than 5\% in all cases, which indicated the degree of accuracy of the model. The effective diffusivity for Moringa oleifera oil through the kernels at $69{ }^{\circ} \mathrm{C}$ was determined for the first time. The value of $0.685 \cdot 10^{-12} \mathrm{~m}^{2} / \mathrm{s}$ fully matched reports of effective diffusion coefficient for other solids.

\section{REFERENCES}

Abdulkareem A, Uthman H, Afolabi AS, Awenebe OL. 2011. Extraction and Optimization of Oil from Moringa Oleifera Seed as an Alternative feedstock for the Production of Biodiesel, in Sustainable Growth and Applications in Renewable Energy Sources. In Tech, Rijeka, pp. 244-268. https:/doi. org/10.5772/2433

Adegbe A, Larayetan R, Omojuwa T. 2016. Proximate Analysis, Physicochemical Properties and Chemical Constituents Characterization of Moringa Oleifera (Moringaceae) Seed Oil Using GC-MS Analysis. Am. J. Chem. 6, 23-28. https:// doi.org/10.5923/j.chemistry.20160602.01

AnwarF, BhangerM.2003.Analytical characterization of Moringa oleifera seed oil grown in temperate regions of Pakistan. J. Agric. Food Chem. 51, 6558-6563. https://doi.org/10.1021/jf0209894

Anwar F, Rashid U. 2007. Physico-chemical characteristics of Moringa oleifera seeds and seed oil from a wild provenance of Pakistan. Pak. J. Bot. 39, 1443-1453.

Ayerza R. 2011. Seed yield components, oil content, and fatty acid composition of two cultivars of moringa (Moringa oleifera Lam.) growing in the Arid Chaco of Argentina. Industrial Crops Prod. 33, 389-394. https://doi.org/10.1016/j. indcrop.2010.11.003

Cacace J, Mazza G. 2003. Mass transfer process during extraction of phenolic compounds from milled berries. J. Food Eng. 59, 379-389. https:// doi.org/10.1016/S0260-8774(02)00497-1

Carrín ME,CapristeGH.2008. Mathematical modeling of vegetable oil-solvent extraction in a multistage horizontal extractor. J. Food Eng. 85, 418. https:// doi.org/10.1016/j.jfoodeng.2007.08.003

Díaz Y, Tabio D, Goyos L, Fernández E, Muñoz S, Piloto R, Verhelst S. 2017. Extraction and characterization of oil from Moringa oleifera for energy purpuses. Wulfenia 24, 86-103.

Díaz Y, Tabio D, Goyos L, Fernández E, Rondón M, Fischer T, Piloto R. 2019. Rheological behavior and properties of biodiesel and vegetable oil from Moringa oleifera Lam. Afinidad 587, 83-90. 
Doulia D, Gekas V. 2001. A knowledge base for the apparent mass diffusion coefficient $\left(\mathrm{D}_{\mathrm{EFF}}\right)$ of foods. Int. J. Food Prop. 3, 1-14. https://doi. org/10.1080/10942910009524613

Efeovbokhan VE, Hymore FK, Raji D, Sanni SE. 2015. Alternative solvents for Moringa oleifera seeds extraction. J. Applied Sci. 15, 1073-1082. https://doi.org/10.3923/jas.2015.1073.1082

Falowo AB, Makumbo FE, Idamokoro EM, Lorenzo JM, Afolayan AJ, Muchenje V. 2018. Multifunctional application of Moringa oleifera Lam. in nutrition and animal food products: A review. Int. Food Res. J. 106, 317-334. https://doi. org/10.1016/j.foodres.2017.12.079

Hines AL, Maddox RN, Rodríguez JL. 1987. Mass Transfer-Fundamentals and Applications. Prentice-Hall Hispanoamericana, Mexico.

Kayode O, Kabir A. 2018. Optimization of shelling efficiency of a Moringa oleifera seed shelling machine based on seed sizes. Industrial Crops Prod. 112, 775782. https://doi.org/10.1016/j.indcrop.2018.01.011

Kostic MD, Jokovic NM, Stamenkovic OS, Rajkovic KM, Milic PS, Veljkovic VB. 2014. The kinetics and thermodynamics of hempseed oil extraction byn-hexane. Industrial Crops Prod. 52, 679-686. https://doi.org/10.1016/j.indcrop.2013.11.045

Muharam Y, Putri AD, Hamzah A. 2019. Phenomenological model for prediction of the performance of a slurry bubble column reactor for green diesel production. J. Phys.: Conf. Ser. 1349, 1-8. https://doi.org/10.1088/1742-6596/1349/1/012057

NC (Norma Cubana). 2008. Minerales-Análisis granulométrico por tamizado-Requisitos generales. Oficina Nacional de Normalización. La Habana.

Ortiz J, Navarrete A, Sacramento JC, Rubio C, Acereto P, Rocha JA. 2012. Extraction and Characterization of Oil from Moringa oleifera Using Supercritical $\mathrm{CO}_{2}$ and Traditional Solvents. Am. J. Anal. Chem. 3, 946-949. https://doi.org/10.4236/ajac.2012.312A125

Pfeil M, Piloto R, Díaz Y, Sánchez Y, Melo EA, Denfeld D, Pohl S. 2020. Data on the thermochemical potential of six Cuban biomasses as bioenergy sources. Data brief. 29, 105207. https://doi.org/10.1016/j.dib.2020.105207

Prasad RK. 2009. Color removal from distillery spent wash through coagulation using Moringa oleifera seeds: Use of optimum response surface methodology. J. Hazard. Mater. 165, 804-811. https://doi.org/10.1016/j.jhazmat.2008.10.068
Rashid U, Anwar F, Ashraf M, Saleem M, Yusup S. 2011. Application of response surface methodology for optimizing transesterification of Moringa oleifera oil: biodiesel production. Energy Convers. Manage. 52, 3034-3042. https:// doi.org/10.1016/j.enconman.2011.04.018

Rashid U, Anwar F, Moser BR, Knothe G. 2008. Moringa oleifera oil: A possible source of biodiesel. Bioresour. Technol. 99, 8175-8179. https://doi.org/10.1016/j.biortech.2008.03.066

Reverchon E, Daghero J, Marrone C, Mattea M, Poletto M.1999. Supercritical fractional extraction of fennel seed oil and essential oil: experiments and mathematical modeling. Ind. Eng. Chem. Res. 38, 3069-3075. https://doi.org/10.1021/ie990015+ RosabalJ, Garcel L. 2006. Hidrodinámicay Separaciones Mecánicas. Editorial Félix Varela, Cuba.

Salaheldeen M, Aroua MK, Mariod AA, Cheng SF, Abdelrahman. 2014. An evaluation of Moringa peregrina seeds as a source for bio-fuel. Industrial Crops Prod. 61, 49-61. https://doi.org/10.1016/j. indcrop.2014.06.027

Stamenkovic OS, Djalovic IG, Kostic MD, Mitrovic PM, Veljkovic VB. 2018. Optimization and kinetic modeling of oil extraction from white mustard (Sinapis alba L.) seeds. Industrial Crops Prod. 121, 132-141. https://doi.org/10.1016/j. indcrop.2018.05.001

Tabio D, Espinosa C, Díaz Y, Rondón M, Fernández E, Piloto R. 2018. Extracción etanólica de aceite de semillas de Moringa oleifera. Revista Investig. $y$ Cienc. la Univ. Autónoma Aguascalientes 74, 32-38.

Thomas GC, Krioukov VG, Vielmo HA. 2005. Simulation of vegetable oil extraction in countercurrent crossed flows using the artificial neural network. Chem. Eng. Processing. 44, 581. https:// doi.org/10.1016/j.cep.2004.06.013

Treybal R. 2001. Operaciones con transferencia de masa. McGraw-Hill, United States.

Varzakas TH, Leach GC, Israilides CJ, Arapoglou D. 2005. Theoretical and experimental approaches towards the determination of solute effective diffusivities in foods. Enzyme Microb. Tech. 37, 2941. https://doi.org/10.1016/j.enzmictec.2004.06.015

Zhao S, Zhang D. 2013. A parametric study of supercritical carbon dioxide extraction of oil from Moringa oleifera seeds using a response surface methodology. Sep. Purif. Technol. 113, 9-17. https://doi.org/10.1016/j.seppur.2013.03.041 